\title{
Alkaline phosphatases, B6 vitamers and pre-eclampsia
}

\author{
Medina JA*, Rabelo D, Alves RC and Maria DA \\ Fisiopatologia USP, Institute Butantan, SP, Brazil
}

Dear Editor, when studying potential molecular therapeutic targets in glioblastoma multiforme, we perceive an alternative point of view to understand the pathophysiology of the specific hypertensive disease of gestation. Would be the catalytic deficiency of alkaline phosphatases, in inflammatory syncytiotrophoblast, partially responsible for the preeclampsia hypertension and the seizures?

We explain: alkaline phosphatases are potential markers both of cell undifferentiating as the refractoriness in glioblastomas [1] and our group alluded to the possibility that the catalytic functioning of these promiscuous enzymes [2] could generate, from phosphate substrates, locally cytotoxic products to cancer stem cells.

In addition, the saturation of the enzyme would inhibit the absorption of others physiologically important substrates such the vitamers of B6, whose intracellular transport is obligatorily preceded by the action of alkaline phosphatases [3]. Mutations in the ALPL gene are responsible for the disease neonatal hypophosphatasia; in these neonates showing signs of osteomalacea the alkaline phosphatases are not catalytically effective, leading to death by seizures secondarily to intracellular scarcity of B6 vitamers despite his high extracellular levels [4].

The placenta on pre-eclampsia progressively become insufficient secondary to inflammatory mechanisms similar such the antiphospholipid antibody syndrome [5] and is associated with an immune imbalance where pro-inflammatory CD4 $(+)$ T-cells are increased and $\mathrm{T}$ regulatory cells are decreased [6]. Anatomopathological analysis of placentas from pre-eclampsia patients describes higher concentrations of alkaline phosphatases in syncytiotrophoblast compared to normal gestation [7], and the catalytic activity of alkaline phosphatases in preeclampsia are increased compared to the normal pregnancy [8].

The low functioning of alkaline phosphatases in the acid and inflammatory syncytiotrophoblast may be partially responsible for hypertension and the seizures seeing in pre-eclampsia, since a) vitamin B6 intracellular deficiency produces high blood pressure [9] and seizures [10]. b) there is a direct relationship between the severity of pre-eclampsia and blood levels of alkaline phosphatases [11].c) Despite the preventive antiepileptic mechanism of magnesium sulfate not be totally elucidated [12], it could be related to the fact that magnesium is a cofactor for catalytic actions in alkaline phosphatases $[13,14]$.

If there is in fact a decrease in the catalytic functioning of the alkaline phosphatases in the syncytotrophoblast of pregnant with pre-

Copyright: (C2019 Medina JA. This is an open-access article distributed under the terms of the Creative Commons Attribution License, which permits unrestricted use, distribution, and reproduction in any medium, provided the original author and source are credited. eclampsia and consequent restriction to the absorption of B6 vitamins to the fetus, some heroic measures in emergency room perhaps could help in the control of hypertension and seizures: as the maximal oxygenation added to complex B parenteral; the administration alpha Asfotase, a new drug already used in neonatal hypophosphatasia, or the offer venous of B6 vitamers, already without phosphate group, like pyridoxine hydrochloride.

\section{References}

1. Iwadate Y, Suganami A, Tamura Y, Matsutani T, Hirono S, et al. (2017) The pluripotent stem-cell marker alkaline phosphatase is highly expressed in refractory glioblastoma with DNA hypomethylation. Neurosurgery 2: 248-256. [Crossref]

2. Sunden F, AlSadhan I, Lyubimov A (2017) Differential catalytic promiscuity of the alkaline phosphatase superfamily bimetallo core reveals mechanistic features underlying enzyme evolution. J Biol Chem 292: 20960-20974. [Crossref]

3. Smilari P, Romeo DM, Palazzo P, Meli C, Sorge G (2005) Neonatal hypophosphatasia and seizures. A case report. Minerva Pediatr 57: 319-323. [Crossref]

4. Millán JL, Whyte MP (2016) Alkaline phosphatase and hypophosphatasia. Calcif Tissue Int 98: 398-416. [Crossref]

5. Gibbins KJ, Ware Branch D (2014) Pre-eclampsia as a manifestation of antiphospholipid syndrome: assessing the current status. Lupus 23: 1229-1231. [Crossref]

6. Harmon AC, Cornelius DC, Amaral LM, Faulkner JL, Cunningham MW Jr, et al (2016) The role of inflammation in the pathology of preeclampsia. Clin Sci (Lond) 130 409-419. [Crossref]

7. Mangal A, Gaur U, Jain A, Rath G (2005) Histochemical analysis of placental alkaline phosphatase in hypertensive disorders complicating pregnancy. Anat Soc 5: 293-300.

8. Shevade S (2016) Histology and histochemistry of placenta in pregnancies complicated by preeclampsia.

9. Paulose CS, Dakshinamurti K, Packer S, Stephens NL (1988) Sympathetic stimulation and hypertension in the pyridoxine-deficient adult rat. Hypertension 11: 387-391. [Crossref]

10. Wang HS, Kuo MF (2007) Vitamin B6 related epilepsy during childhood. Chang Gung Med J 30: 396-401. [Crossref]

11. Hunter RJ, Pinkerton JH, Johnston H (1970) Serum placental alkaline phosphatase in normal pregnancy and preeclampsia. Obstetrics \& Gynecology 4: 536-542. [Crossref]

12. Euser AG, Cipolla MJ (2009) Magnesium sulfate for the treatment of eclampsia: a brief review. Stroke 40: 1169-1175. [Crossref]

13. Hung HC, Chang GG (2011) Differentiation of the slow-binding mechanism for magnesium ion activation and zinc ion inhibition of human placental alkaline phosphatase. Protein Science 1: 34-45. [Crossref]

14. Olorunniji FJ, Igunnu A, Adebayo JO, Arise RO, Malomo SO (2007) Cofactor interactions in the activation of tissue non-specific alkaline phosphatase: Synergistic effects of $\mathrm{Zn} 2+$ and $\mathrm{Mg} 2+$ ions. Biokemistri 19.
${ }^{\star}$ Correspondence to: José Artur Medina, Fisiopatologia USP, Institute Butantan SP, Brazil, E-mail: j.a.medina@terra.com.br

Received: February 15, 2019; Accepted: March 01, 2019; Published: March 08, 2019 